\title{
INTERNALISASI NILAI-NILAI RELIGIOSITAS DI MASYARAKAT SUNDA GARUT
}

\author{
Tubagus Chaeru Nugraha
}

Prodi Sastra Arab, Fakultas Ilmu Budaya Universitas Padjadjaran E-mail: tubaguschaeru@gmail.com / t.chaeru@unpad.ac.id

\begin{abstract}
ABSTRAK. Penelitian ini bertujuan untuk mendeskripsikan konsep dan metode internalisasi nilai-nilai religiositas (INR) di empat masjid besar Kab. Garut. Dari hasil kajian ini dapat dipetakan kemampuan integrasi urang Sunda Garut dalam ekspresi sikap berdasarkan kaidah transidental. Dalam kajian selanjutnya diharapkan dapat menjadi salah satu model pembentukan karakter tangguh urang Sunda. Dalam perspektif Systemic Functional Lingusitics (SFL), karakter diinterpretasikan sebagai realisasi operasional jati diri atau identitas seseorang atau suatu bangsa (Saragih, 2012). Untuk memperoleh hasil analisis yang akurat, penelitian ini dilakukan dengan tiga langkah.Pertama, metode penyediaan data secara deskriptif yang dilakukan dengan metode simak, survei, wawancara, dan kuosioner.Kedua, untuk analisis digunakan pendekatan eklektika critical discourse analysis (CDA)-Sistemik, hasilnya diolah secara kualitatif kemudian diinterpretasi untuk memperoleh model INR. Objek kajian dalam penelitian ini adalahekspresi INR di masjid Agung Garut Kota, masjid besar Tarogong Kaler, masjid besar Bayongbong, dan masjid besar Leles. Hasil penelitian berupa kategorisasi ekspresi sikap urang Sunda Garut berdasarkan kaidah hukum alam, kaidah intelektual, kaidah sosial, dan kaidah transidental. Kedua, model hirarki kaidah ekspresi sikap urang Sunda Garut sehingga terbentuklah karakter yang tangguh. Ketiga, ekspresi religiositas urang Sunda Garut meliputi lima dimensi, yaitu; (1) Ekspresi sikap pada keyakinan agama; (2) Ekspresi sikap terhadap ibadat; (3) Ekspresi sikap terhadap pengetahuan agama; (4) Ekspresi tentang pengalaman agama; (5) ekspresi sikap konsekuen pada aktualisasi dari konsep agama yang terinternalisasi dalam jiwanya.
\end{abstract}

Kata Kunci: Internalisasi, Nilai-Nilai Religiositas, dan Karakter

\section{INTERNALIZATION VALUE RELIGIOSITY IN SOCIETY SUNDA GARUT}

\begin{abstract}
This study aimed to describe the concepts and methods of internalization of religiosity values (IRV) in four large mosques in Garut district. The results of this study can be mapped into the integration of capabilities of Sundanese people in Garut in expression based transcendental rules attitude. The further study of this research is expected to create the models of the formation of strong character from Sundanese people. To obtain the accurate analysis results, the study is conducted in three steps. First, the method of providing descriptive data is done with reference, surveys, interviews, questionnaire, and documentation study methods. Secondly, to achieve this purpose, it uses an approach of critical discourse analysis (CDA). The first result expected from this research is the categorization of attitude expression from Sundanese people in Garut based on principles of natural law principles, the rules of intellectual, social norms, and transcendental rules. Second, the hierarchical model of attitude expression of Sundanese people in Garut so it impacts the tough character.Third, the expression of religiosity from Sundanese people in Garut including five dimensions, namely; (1) The expression of attitude on religious beliefs; (2) The expression of attitudes towards worship; (3) The expression of attitude towards religious knowledge; (4) The expression of religious experience; (5) the expression of an attitude consequent upon the actualization of the concept of internalized religion in their soul.
\end{abstract}

Key words :Internalization, Religiosity Values, Character.

\section{PENDAHULUAN}

Internalisasi dalam KBBI (2005:439) adalah nomina yang menunjukkan penghayatan secara mendalam sehingga menjadi sebuah keyakinan dan kesadaran, sedangkan dalam bahasa Arab dikenal istilah ishfau sh-shifati $d z$-dzatiyati atau istimaji 'l-ma'ayir berarti 'penerimaan standar'. Menurut Badawi (1993:223) dalam A Dictionary of The Social Sciences, teori internalisasi (binau 'sy-syakhshiyyati) merupakan sistem yang tersusun dari sekumpulan karakter jasmaniyah, naluriyah, kecakapan, pola pikir yang menentukan ciri khas seseorang.
Nilai-nilai, bisa berarti nilai budaya (KBBI, 2002: 783) yaitu: konsep abstrak mengenai masalah dasar yang sangat penting dan bernilai dalam kehidupan manusia. Dalam konteks penelitian ini, nilai budaya yang berkaitan dengan kearifan lokal (local wisdom) atau local genius. Wisdom dalam istilah bahasa Arab dikenal dengan hikmah, yaitu: Al-ma'rifatu 'l-kamilatu likulli mayastathi'u 'l-insan an ya'rifa litadbiri hayati au lihifzhi shihhathi (Badawi 1993: 447). Adapun definisi kearifan lokal dalam penelitian ini adalah usaha manusia dengan menggunakan akal budinya (kognisi) dan proses belajar budaya (enkulturasi) untuk bertindak dan bersikap terhadap sesuatu, objek, atau peristiwa 
yang terjadi dalam ruang tertentu. Satu di antara berbagai nilai kearifan lokal adalah nilai keagamaan, yaitu konsep keagamaan (religiositas) yang dianggap suci oleh masyarakat sebagai pedoman tingkah lakunya.

Religiositas menurut KBBI (2005:944) merupakan nomina yang bermakna pengabadian terhadap agama atau kesalehan.Adapun kasundaan menurut Tamsya (2002:866) adalah gabungan konfiks /ka-an/ dengan sunda memiliki makna adjektif, bersifat kesundaan. Jadi, internalisasi nilai-nilai religiositas kasundaan dapat dipahami sebagai penghayatan pada pedoman atau standar yang digunakan masyarakat dalam pengabdian terhadap agama yang bersifat kasundaan, diungkapkan dengan bahasa Sunda dengan proses belajar budaya (enkulturasi).

Dalam perspektif Systemic Functional Linguistics (SFL) karakter diinterpretasikan sebagai realisasi operasional jati diri atau identitas seseorang atau suatu bangsa (Saragih, 2012: 29). Dengan kata lain, jati diri bersifat konseptual, sedangkan karakter bersifat operasional. Hubungan bahasa dengan jati diri dan karakter suatu suku, bangsa adalah hubungan realisasi. Contohnya, tata bahasa Inggris berupa tense, singular, dan persons telah membangun jati diri mereka yang tepat waktu, cermat angka, dan sadar posisi atau kedudukan. Realisasi bangsa Eropa memiliki karakter individualis, kreatif, dan inovatif. Berbeda dengan bangsa Jepang dalam bahasanya terdapat konsep bonsai, budaya mengecilkan atau mengerdilkan sesuatu yang besar agar berterima dalam ruang terbatas. Realisasi bangsa Jepang memiliki karakter pemodifikasi atau peniru.

Menurut Saragih (2012:31), bangsa Indonesia memiliki karakter berdasarkan etika universal dan etika spesifik. Karakter universal bangsa Indonesia adalah berani berjuang sampai titik darah penghabisan. Realisasinya berupa keyakinan kepada Tuhan, ramah, setia, penyayang, malu dan lain-lain. Adapun karakter khususnya sesuai dengan hikmah budaya daerah. Contoh karekter urang Sunda, menurut Hayati (2011) masyarakat Sunda Kampung Naga memiliki budaya papagon hirup. Realisasi papagon hirup ini berupa nilai-nilai kearifanlingkungan seperti pamali 'tabu'.

Objek kajian dalam penelitian ini adalah ekspresi INR di masjid Agung Garut Kota, masjid besar Tarogong Kaler, masjid besar Bayongbong, dan masjid besar Leles. Keempat masjid besar ini dapat dijadikan sampel populasi masjid di kabupaten Garut, Jawa Barat, Indonesia.

Berdasarkan Kantor Departemen Agama Kabupaten Garut, tahun 2014, jumlah masjid 4.998 buah. Adapun jumlah pondok pesantrennya 1.053, dengan jumlah santri kurang-lebih 79 ribu. Berdasarkan perhitungan Dinas Kependudukan dan Pencatatan Sipil tahun 2013 disesuaikan dengan registrasi mutasi penduduk, jumlah penduduk muslim Kabupaten Garut tercatat sebanyak 2.308.638jiwa.
Masjid berbeda dengan langgar dan mushala dari aspek fisikinya saja.Masjid, langgar, mushala merupakan tempat ibadah umat Islam.Masjid berasal dari kata /sjd/ 'sujud' $\rightarrow$ /masjid/ 'tempat sujud' atau peribadatan.Masjid selain pusat peribatan, seperti shalat berjamaah, belajar Al-Quran, disksusi agama; secara historis juga sebagai pusat aktivitas sosial, bahkan kemiliteran. Di antara masalah fungsi masjid pada saat ini hanya berfungsi sebagai pusat ibadah (ritual); belum mengoftimalkan fungsi edukasi, fungsi sosial, fungsi budaya, fungsi politis, dan lain-lain.

Ciri-ciri fisik masjid sebagai pusat ibadah ada lima. Penjelasannya adalah sebagai berikut: (1) ruang utama, tempat shalat berjamaah; (2) Mihrab, tempat imam memimpin shalat; (3) mimbar, tempat khatib menyampaikan khutbah; (4) menara, tempat muadzin mengumandangkan adzan; (5) kubah, ciri khas masjid; dan (5) tempat bersuci, untuk berwudhu. Adapun masjidmasjid modern biasanya dilengkapi dengan fasilitas klinik kesehatan, perpustakaan, dan tempat olah-raga.

Adapun ciri-ciri non fisik masjid, adalah (1) ada seorang Imam masjid, harus laki-laki, berakhlak islamiyah dan memahami dengan mandalam agama Islam; (2) ta'mir masjid, dewan keluarga masjid (DKM) yaitu: pengurus masjid yang bertugas memakmurkan masjid baik secara fisik, maupun dengan berbagai kegiatan keummatan; (3) adanya pemisahan jama'ah pria (ikhwan) dan wanita (akhwat).

Menurut Nugraha (2011:1) kategorisasi ekspresi sikap urang Sunda ada berdasarkan kaidah hukum alam, kaidah intelektual, kaidah sosial, dan kaidah transidental. Dalam penelitian ini difokuskan pada aplikasi kaidah transidental. Aplikasi kaidah transidental urang Sunda meliputi lima dimensi sikap, yaitu:
1) sikap pada keyakinan agama
2) sikap terhadap ibadat
3) sikap terhadap pengetahuan agama
4) sikap tentang pengalaman agama
5) sikap konsekuen pada aktualisasi dari konsep agama yang dihayati

Disamping itu, bagaimana peran masjid dalam mengoftimalkan fungsi budaya (kulturisasi) pembinaan dengan bahasa Sunda. Hal inilah yang menjadi motivasi peneliti untuk memerikan 'internalisasi’ nilai-nilai Religiositas Di Masyarakat Sunda, Garut.

Berdasarkan latar belakang tersebut dapat diidentifikasi masalah sebagai berikut:

1. Bagaimana konsep, metode, dan teknik internalisasi (bina'u syakhshiyyah) atau pembinaan karakter di keempat masjid besar Kab. Garut

2. Bagaimana kualitas internalisasi (bina'u syakhshiyyah) atau pembinaan karakter di keempat masjid besar Kab. Garut 


\section{METODE}

Untuk memperoleh hasil analisis yang akurat, penelitian ini dilakukan dengan tiga langkah.Pertama, metode penyediaan data dengan metode survey, kuosionerwawancara (Mahsun, 2005:92-103).Kedua, untuk analisis wacana kritis atau critical discourse analysis (CDA) AlWasilah (2004:13), dan Pennycook (2001:80). Ketiga, metode dan teknik penyajian hasil analisis data.

\section{Penyediaan Data}

Penyediaan data secara deskriptif dilakukan dengan metode survey, kuosioner-wawancara. Penyediaan data dilakukan berdasarkan (a) membuat instrument kuosioner-lembar wawancara (K-LW) ; (b) uji coba instrument K-LW; (c) Revisi instrument K-LW. Teknik yang digunakan dalam penelitian ini adalah teknik dasar, yaitu teknik sadap.Selanjutnya, teknik catat (Mahsun, 2005:92-103).

\section{Analisis Data}

Metode yang digunakan dalam kajian ini, adalah critical discourse analysis (CDA). Menurut Al-Wasilah (2004:13), CDA adalah salah satu bentuk pendekatan dalam cultural studies (CS), Bandingkan denganCohen, L. 1994.

Dari kedelapan prinsip tersebut yang sesuai dengan penelitian ini adalah prinsip pertama, yaitu problematika sosial, tentang pembinaan jama'ah masjidmasjid besar kabupaten garut. Prinsip kedua, pendekatan sosio-kognitif akan terpetakan sistem pembinaan masjid. Ketiga, interpretatif dan eksplanatif data kuosioner yang tersedia berupa deskripsi sistem pembinaan masjid.

Pendekatan penelitian ini bersifat deksripsitf non hipotesis.Sesuai dengan masalah dan tujuan penelitian, maka data dianalisis menggunakan deksriptif prosentase.Arikanto (2006) menyatakan bahwa pada umumnya bersifat non hipotesis.

Analisis deskriptif prosentase diambil berdasarkan populasi dan sampel. Populasi adalah wilayah generalisasi yang terdiri atas objek/ subjek yang mempunyai kualitas dan karakteristik tertentu yang ditetapkan oleh peneliti untuk dipelajari dan kemudian ditarik kesimpulannya (Sugiyono, 2006).Selanjutnya, menurut Arikunto (2006), populasi adalah keseluruhan subjek penelitian.

Berdasarkan data Depag Garut (2014), perbandingan sarana ibadah (masjid: 4.998; Langgar: 5.880; Mushola: 3.350) dengan jumlah penduduk muslim adalah 14.228 per 2.308.638jiwa. Rata-rata jama'ah pada setiap masjid atau mushala atau langgar adalah 1:162; satu banding 162 jama'ah. Sedangkan, rata-rata tanggung jawab pembina (ulama, ustadz, mubaligh, guru ngaji, dan penyuluh agama Islam) adalah 1:135; satu orang membina 135 jama'ah. Jadi populasi dari 4 masjid rata-rata 648 orang, adapun sampel yang diambil adalah 96 jama'ah. http://www.garutkab.go.id/pub/static_menu/ detail/sosbud_agama_sarana_pontren

Sampeladalah bagian darijumlah dan karakteristik yang dimiliki oleh populasi tersebut (Sugiyono, 2006). Selanjutnya Arikunto (2006), sampel adalah sebagian atau wakil populasi yang diteliti. Sampel dalam penelitian ini adalah 96 orang jama'ah masjid.

\section{HASIL DAN PEMBAHASAN}

Berdasarkan hasil kuosioner dari populasi 200, sampel penelitian ini adalah 96jama'ah 4 masjidbesar, kab. Garut. Hasil instrumen yang diperoleh dari input, proses dan output kuosiner mengadaptasi pedoman konversi tingkat keberhasilan dalam prosentasi. Skalanya adalah: (1). 0\%-20\% (sangat rendah); (2). 21\%-40\% (rendah); (3). 41\%-60\% (cukup); (4). 61\%-80\% (tinggi); dan (5). $81 \%-100 \%$ (sangat tinggi). Analisis data dapat diperoleh dengan menganalisis jawaban responden terhadap kuosioner dengan menghitung prosentasinya. 1). /TT/ ' Tidak Tahu'; 2). /STS/ 'sangat tidak setuju'; 3)./ TS/ 'tidak setuju'; 4)./S/ 'setuju'; 5). /SS/ 'sangat setuju'

\section{Hasil Kuosioner}

Tabel 1 berikut dapat ditafsirkan bahwa 100\% jama'ah masjid yakin bahwa yang menentukan rizki hanya Allah.

\section{Tabel 1. Keyakinan Rizki dari Allah}

\begin{tabular}{ccc}
\hline \multicolumn{3}{c}{ Aqidah Islam } \\
\hline SS & 88 & $92 \%$ \\
S & 8 & $8 \%$ \\
TS & 0 & $0 \%$ \\
STS & 0 & $0 \%$ \\
TT & 0 & $0 \%$ \\
\hline
\end{tabular}

Tabel 2 berikut menyebutkan bahwa 93\% jama'ah masjid telah memahami bahwa muslim wajib bekerja, Walaupun masih ada 5\% yang tidak setuju; dan 2\% tidak tahu. 'Digawe, saperti dagang jeung sagala usaha jelema, ngan sakadar sabab (hal) anu ngamungkinkeun datangna rezeki.'

Tabel 2. Manusia wajib bekerja

\begin{tabular}{ccc}
\hline \multicolumn{3}{c}{ Syari'at (Kerja) } \\
\hline SS & 60 & $63 \%$ \\
S & 29 & $30 \%$ \\
TS & 2 & $2 \%$ \\
STS & 3 & $3 \%$ \\
TT & 2 & $2 \%$ \\
\hline
\end{tabular}

Tabel 3 berikut menunjukkan bahwa 98\% jama'ah masjid telah memahami ikhtiar nafkah harus yang halal. 'Dumasar kana kayakinan diluhur, kawajiban jelema mah usaha jeung ikhtiar kalawan make cara nu halal.'

Tabel 3. Wajib Ikhtiar yg halal

\begin{tabular}{ccc}
\hline \multicolumn{3}{c}{ Kerja Halal } \\
\hline SS & 77 & $80 \%$ \\
S & 17 & $18 \%$ \\
TS & 0 & $0 \%$ \\
STS & 0 & $0 \%$ \\
TT & 2 & $2 \%$ \\
\hline
\end{tabular}


Tabel 4 berikut menginformasikan bahwa 96\% jama'ah masjid meyakiniriba haram. Renten saperti bunga bank, bunga defosito, tukang ngarentenkeun, jeung anu saperti eta hukumna haram, wajib dijauhan jeung ditinggalkeun

Tabel 4. Riba Haram

\begin{tabular}{ccc}
\hline & Riba & \\
\hline SS & 69 & $72 \%$ \\
S & 23 & $24 \%$ \\
TS & 2 & $2 \%$ \\
STS & 1 & $1 \%$ \\
TT & 1 & $1 \%$ \\
\hline
\end{tabular}

Tabel 5 berikut mengungkapkan bahwa 97\% jama'ah masjid memahami wajib zakat harta. 'Satiap muslim, upama hartana geus nepi kana nisab (ukuran lobana harta) zakat, wajib ngaluarkeun zakat hartana (tina hasil dagang, tatanen, jeung nu sejenna).'

Tabel 5. Wajib zakat harta

\begin{tabular}{ccc}
\hline \multicolumn{3}{c}{ Zakat Harta } \\
\hline SS & 64 & $67 \%$ \\
S & 29 & $30 \%$ \\
TS & 0 & $0 \%$ \\
STS & 2 & $2 \%$ \\
TT & 1 & $1 \%$ \\
\hline
\end{tabular}

Tabel 6 berikut melaporkan bahwa 98\% jama'ah masjid memahami bahwa shadaqah sunnah. 'Satiap muslim disunnatkeun pikeun shodaqoh, infak ngawangun masjid, meuncit qurban, jeung sajabana anu dicontokeun $\mathrm{ku}$ Rasul Allah SAW.'

Tabel 6. Shadaqah sunnah

\begin{tabular}{ccc}
\hline \multicolumn{3}{c}{ Shadaqah } \\
\hline SS & 57 & $59 \%$ \\
S & 37 & $39 \%$ \\
TS & 1 & $1 \%$ \\
STS & 1 & $1 \%$ \\
TT & 0 & $0 \%$ \\
\hline
\end{tabular}

Tabel 7 berikut menemukan bahwa 99\% jama'ah masjid mengerti kewajiban berbusana muslimah. 'Pikeun kaum muslimah nalika aya di luar imah, wajib make pakean muslimah nu nutup orat, dijilbab, jeung make tiung.'

Tabel 7. Wajib berjilbab

\begin{tabular}{ccc}
\hline \multicolumn{3}{c}{ Busana Muslimah } \\
\hline SS & 79 & $82 \%$ \\
S & 16 & $17 \%$ \\
TS & 0 & $0 \%$ \\
STS & 1 & $1 \%$ \\
TT & 0 & $0 \%$ \\
\hline
\end{tabular}

Tabel 8 berikut menjelaskan bahwa 93\% jama'ah masjid memahami pria wajib memberi nafkah. 'Islam marentahkeun nganafakahan kulawarga (anak pamajikan) pikeun bapa, salaki, jeung lalaki nu geus baleg, sarta waras.'

Tabel 8. Pria wajib menafkahi

\begin{tabular}{ccc}
\hline \multicolumn{3}{c}{ Nafkah Keluarga } \\
\hline SS & 60 & $63 \%$ \\
S & 29 & $30 \%$ \\
TS & 4 & $4 \%$ \\
STS & 0 & $0 \%$ \\
TT & 3 & $3 \%$ \\
\hline
\end{tabular}

Tabel 9 berikut dapat dipahami bahwa 97\% jama'ah masjid mamahami peran utama muslimah. 'Kewajiban nu utama pikeun istri, jadi indung nu ngatik ngadidik anakna, ngurus rumah tangga, jeung ngajaga harta banda salaki.'

Tabel 9. Peran utama wanita di rumah

\begin{tabular}{ccc}
\hline \multicolumn{3}{c}{ Peran Wanita } \\
\hline SS & 16 & $54 \%$ \\
S & 13 & $43 \%$ \\
TS & 0 & $0 \%$ \\
STS & 0 & $0 \%$ \\
TT & 1 & $3 \%$ \\
\hline
\end{tabular}

Tabel 10 berikut dapat ditafsirkan bahwa 97\% jama’ah masjid memahami kewajiban berbakti kepada kedua orang tua. 'Urang sarerea teh anak kolot urang, kusabab eta urang wajib babakti ka duanana, naha nalika jumeneng atawa tos tilar dunya.'

Tabel 10. Berbakti kepada Kedua Orang tua

\begin{tabular}{ccc}
\hline \multicolumn{3}{c}{ Birrul Walidain } \\
\hline SS & 77 & $80 \%$ \\
S & 16 & $17 \%$ \\
TS & 2 & $2 \%$ \\
STS & 0 & $0 \%$ \\
TT & 1 & $1 \%$ \\
\hline
\end{tabular}

Tabel 11 berikut mengungkapkan bahwa 99\% jama'ah masjid berniat memperkuat Keyakinan 'Abdi ngiring pangaosan umum di masjid ieu minggonan/ tiap ahad, didorong ku kahoyong nambihan kayakinan ka Allah.'

Tabel 11. Motivasi Keyakinan

\begin{tabular}{ccc}
\hline & Motiv Aqidah \\
SS & 72 & $75 \%$ \\
S & 23 & $24 \%$ \\
TS & 0 & $0 \%$ \\
STS & 0 & $0 \%$ \\
TT & 1 & $1 \%$ \\
\hline
\end{tabular}


Tabel 12 berikutmenunjukkan bahwa 98\% jama'ah masjidberniat menambah wawasan 'Abdi ngahadiran gemblengan umum di masjid ieu tiap minggon kanggo nambihan luang dina elmu-elmu kaislaman.'

\section{Tabel 12. Motivasi wawasan}

\begin{tabular}{ccc}
\hline \multicolumn{3}{c}{ Motiv Wawasan } \\
\hline SS & 61 & $64 \%$ \\
S & 33 & $34 \%$ \\
TS & 0 & $0 \%$ \\
STS & 0 & $0 \%$ \\
TT & 2 & $2 \%$ \\
\hline
\end{tabular}

Tabel 13 berikut dapat ditafsirkan bahwa 97\% jama'ah masjid berniat silaturahmi. 'Abdi ngahadiran gemblengan umum di sababaraha masjid di Garut, kanggo silahturahmi.'

\section{Tabel 13. Motivasi Silaturahmi}

\begin{tabular}{ccc}
\hline \multicolumn{3}{c}{ Silaturahmi } \\
\hline SS & 45 & $47 \%$ \\
S & 48 & $50 \%$ \\
TS & 1 & $1 \%$ \\
STS & 0 & $0 \%$ \\
TT & 2 & $2 \%$ \\
\hline
\end{tabular}

Tabel 14 berikutmenyebutkan bahwa 98\% jama'ah masjidsetuju materi pembinaan yang utama: Aqidah, ibadah dan akhlak. 'Bahan pangaosan anu paling dipikaseneng ku abdi di masjid ieu nyaeta Aqidah Islam, Ibadah, sareng Akhlaq.'

Tabel 14. Materi yang diperlukan

\begin{tabular}{ccc}
\hline \multicolumn{3}{c}{ Materi Kajian } \\
\hline SS & 63 & $66 \%$ \\
S & 31 & $32 \%$ \\
TS & 0 & $0 \%$ \\
STS & 0 & $0 \%$ \\
TT & 2 & $2 \%$ \\
\hline
\end{tabular}

Tabel 15 berikut melaporkan bahwa 80\% jama'ah masjid menyadari pentingnya shalat berjama'ah. 'Abdi tiap dinten sholat berjama'ah di masjid ieu, utamina waktos solat Isya jeung shubuh.'

Tabel 15. Sadar penting shalat berjama'ah

\begin{tabular}{ccc}
\hline \multicolumn{3}{c}{ Sholat Berjama'ah } \\
\hline SS & 39 & $41 \%$ \\
S & 37 & $39 \%$ \\
TS & 12 & $12 \%$ \\
STS & 1 & $1 \%$ \\
TT & 7 & $7 \%$ \\
\hline
\end{tabular}

Tabel 16 berikut mengungkangkan bahwa 95\% jama'ah masjid memahami kewajiban berda'wah. 'Abdi sering ngajak kulawarga abdi kanggo ngiring rupi-rupi kagiatan kaagamaan di masjid ieu (sapertos sholat barjama'ah, shodaqah, pengaosan umum, jeung sajabana).'

Tabel 16. Tugas berda'wah

\begin{tabular}{ccc}
\hline \multicolumn{3}{c}{ Da'wah } \\
\hline SS & 59 & $62 \%$ \\
S & 32 & $33 \%$ \\
TS & 3 & $3 \%$ \\
STS & 0 & $0 \%$ \\
TT & 2 & $2 \%$ \\
\hline
\end{tabular}

Tabel 17 berikut menemukan bahwa 97\% jama' ah masjid memiliki kesadaran untuk mengajak keluarga. 'Abdi sok ngadugikeun deui eusi pengaosan ka anggota kulawargi, sareung tatanggi sabundeureun abdi.'

\section{Tabel 17. Da'wah di keluarga}

\begin{tabular}{ccc}
\hline \multicolumn{3}{c}{ Da'wah Keluarga } \\
\hline SS & 48 & $50 \%$ \\
S & 43 & $45 \%$ \\
TS & 2 & $2 \%$ \\
STS & 0 & $0 \%$ \\
TT & 3 & $3 \%$ \\
\hline
\end{tabular}

Tabel 18 berikut menjelaskan bahwa 97\% jama'ah masjid penting bermu'amalah Islami. 'Abdi peryogi ngartos kana aturan Islam kumaha cara natangga, digawe, dagang, sareng cara hirup kumbuh jeung batur.'

Tabel 18. Mua'amalah Islami

\begin{tabular}{ccc}
\hline \multicolumn{3}{c}{ Mu'amalah } \\
\hline SS & 71 & $74 \%$ \\
S & 23 & $24 \%$ \\
TS & 0 & $0 \%$ \\
STS & 0 & $0 \%$ \\
TT & 2 & $2 \%$ \\
\hline
\end{tabular}

Tabel 19 berikut dapat ditafsirkan bahwa 97\% jama'ah masjid setuju materi aturan profesi Islami. 'Abdi peryogi ngartos kana aturan Islam anu pakuat pakait sareung kaahlian (saperti tani, dagang, jadi pagawe, dokter, guru jeung sajabana) sangkan hirup abdi berekah tur guligah.'

\section{Tabel 19. Materi profesi Islami}

\begin{tabular}{ccc}
\hline \multicolumn{3}{c}{ Aturan Profesi } \\
\hline SS & 69 & $72 \%$ \\
S & 21 & $22 \%$ \\
TS & 1 & $1 \%$ \\
STS & 0 & $0 \%$ \\
TT & 5 & $5 \%$ \\
\hline
\end{tabular}

Tabel 20 berikut menunjukkan bahwa 90\% jama'ah masjid setuju bahwa masjid sebagai pusat ibadah, pendidikan, pembinaan generasi yang membangun peradaban Islam. 'Menurut Abdi mah, masjid teh lain 
ngan saukur tempat ibadah nu mahdhah, tapi oge pikeun puser didikan, geblengan pikeun ngawangun umat nu punjul dina mapag paradaban Islam anu Agung.

\section{Tabel 20. Materi profesi Islami}

\begin{tabular}{ccc}
\hline \multicolumn{3}{c}{ Jamaah Masjid } \\
\hline SS & 67 & $70 \%$ \\
S & 19 & $20 \%$ \\
TS & 5 & $5 \%$ \\
STS & 2 & $2 \%$ \\
TT & 3 & $3 \%$ \\
\hline
\end{tabular}

\section{Pembahasan Internalisasi NRK}

Sistem Pembinaan Masjiddidasarkan pada firmah Allah,Q.S. Taubah,9:18\&108, yang artinya: (1). Sesungguhnya yang memakmurkan masjid Allah hanyalah orang-orang yang beriman kepada Allah dan hari kemudian, serta menegakkan sholat (tetap) melaksanakan zakat dan tidak takut (kepada apa pun) kecuali kepada Allah, maka mudah-mudahan mereka termasuk orang-orang yang mendapat petunjuk; dan (2) Sungguh masjid yang didirikan atas dasar taqwa, sejak hari pertama adalah lebih pantas engkau melaksanakan shalat di dalamnya. Di dalamnya ada orang-orang yang ingin membersihkan diri.Allah menyukai orang-orang yang bersih.

Berdasarkan dua ayat tersebut diatas, maka pola pembinaan nilai-nilai religiositas meliputi lima dimensi, yaitu; (1 )Aqidah Islam; (2) kaidah-kaidah ibadat; (3) wawasan atau pengetahuan agama; (4) pengalaman keagamaan; (5) aktualisasi nilai-nilai agama yang terinternalisasi dalam jiwa.

\section{Kaidah Aqidah Islam (Keyakinan)}

Pembahasan aqidah dalam Islam merupakan pembahasan yang paling penting dan mendasar dibandingkan dengan perkara lainnya. Hal ini disebabkan kedudukan aqidah Islam merupakan asas, kaidah berfikir, tolak-ukur perbuatan, dan patokan bagi manusia ketika memecahkan problematika kehidupan dunia yang dihadapinya. Aqidah inilah yang menentukan cara pandang (point of view) seorang manusia, cita-cita, dan tujuan kehidupannya.

Berdasarkan hasil kuosioner tersebut dia atas bahwa:

1. $100 \%$ jama'ah masjid yakin bahwa yang menentukan rizki hanya Allah(tabel 1)

2. $99 \%$ jama'ah masjid berniat memperkuat Keyakinan (tabel 11)

3. bahwa $98 \%$ jama'ah masjid setuju materi pembinaan yang utama: Aqidah, ibadah dan akhlak (tabel 14)

4. $97 \%$ jama'ah masjid setuju bahwa masjid sebagai pusat ibadah, pendidikan, pembinaan generasi yang membangun peradaban Islam (tabel 20).
Keempat hal ini menunjukkan bahwa aqidah dalam Islam menjadi landasan bagi jamaah masjid untukmembangun peradaban manusia sesuai dengan fitrah manusia. Aqidah sebagai dasar pijakan kebudayaan yang akan melahirkan berbagai aturan, hukum, undangundang, dan tata-nilai dengan segenap turunannya (derivate values).

Dengan demikian, kedudukan aqidah dalam Islam menjadi sangat penting dan menentukan, karena aqidah menjadi sesuatu yang diyakini kebenarannya, diperjuangkan keberadaannya, dipertahankan eksistensinya, dan disampaikan kepada seluruh umat manusia sebagai rahmatan lil 'âlamîn.

\section{Kaidah Beribadah}

Al-Qur'an Al-Karim mengungkapkan gambaran yang jelas mengenai apa, mengapa, hendak kemana manusia, perhatikan ayat-ayat Al-Qur'an Al-Karim tentang hal tersebut QS Al-Baqarah:30 (khalifah di bumi);As-Sajadah:9 (bersyukur); dan Adz-Dzariyat:56 (beribadah kepada Allah).

Berdasarkan hasil kuosioner tersebut diatas bahwa:

1. $97 \%$ jama'ah masjid memahami wajib zakat harta (tabel 5).

2. $99 \%$ jama'ah masjid mengerti kewajiban berbusana muslimah (tabel 7)

3. $95 \%$ jama'ah masjid memahami kewajiban berda'wah (tabel 16)

4. $97 \%$ jama'ah masjid setuju materi aturan profesi Islami (tabel 19).

Keempat hal ini menunjukkan bahwa jama'ah yang terbina di keempatmasjid Besar di Garut mempunyai visi sebagai khalifah di muka bumi. Mereka memiliki misi beribadah kepada Allah SWT dalamseluruh aspek kehidupan.

\section{Wawasan Hukum Islam}

Berdasarkan hasil kuosioner tersebut diatas bahwa:

1. $93 \%$ jama'ah masjid telah memahami bahwa muslim wajib bekerja(tabel 2).

2. $96 \%$ jama'ah masjid meyakini riba haram(tabel 4 ).

3. $98 \%$ jama'ah masjid memahami bahwa shadaqah sunnah(tabel 6).

4. $98 \%$ jama'ah masjid berniat menambah wawasan (tabel 12).

Hal ini terbukti, misalnya jama'ah masjid besar Bayongbong juga sering mengikuti acara pengajian di masjid-masjid lainnya. Contoh lain, di masjid Agung dan masjid tarogong Kaler, para pengisi materi pengajiannya merupakan wakil dari berbagai ormas yang ada di wilayah Garut sehingga wawasan jama'ah masjid bertambah luas. 


\section{Pengalaman Beragama}

Berdasarkan hasil kuosioner tersebut diatas bahwa:

1. $93 \%$ jama'ah masjid memahami pria wajib memberi nafkah(tabel 8).

2. $97 \%$ jama'ah masjid mamahami peran utama muslimah(tabel 9).

3. $97 \%$ jama'ah masjid memahami kewajiban berbakti kepada kedua orang tua(tabel 10).

4. 97\% jama'ah masjid memiliki kesadaran untuk mengajak keluarga(tabel 17).

\section{Aktualisasi Konsep}

Berdasarkan hasil kuosioner tersebut diatas bahwa:

1. $98 \%$ jama'ah masjid telah memahami ikhtiar nafkah harus yang halal (tabel 3).

2. $97 \%$ jama'ah masjid berniat silaturahmi(tabel 13).

3. 97\% jama'ah masjid penting bermu'amalah Islami(tabel 18).

4. $97 \%$ jama'ah masjid setuju materi aturan profesi Islami(tabel 19).

Secara umum masyarakat Garut yang berhaji dari prosentasi meningkat lima tahun tahun terakhir (20102014) $0.041 \%$; $0.049 \% ; 0.048 \% ; 0.071 \%$; $0.080 \%$. Arti dari $0.080 \%$ adalah ada seorang yang berhaji pada setiap jumlah penduduk 1245. Adapun yang berzakat fitrah jumlah zakat yang terkumpul Rp. 16.835.102.800 (16 triliyun). Bila dibandingkan dengan jumlah penduduk rata-rata besaran zakat hanya Rp. 1245.

\section{SIMPULAN}

Berdasarkan pembahasan tersebut di atas dapat diambil simpulan sebagai berikut: Kualitas internalisasi nilai-nilai religiositas (INR) jama'ah empat masjid besar adalah sangat baik. Hanya saja dari aspek kuantitas jama'ah dari rata-rata kavasitas setiap masjid relatif masih kurang karena baru $15 \%$; Model INR dilakukan secara umum dan khusus; jenis INR yang umum berupa khutbah jum'at dan pengajian umum. Jenis INR khusus terbatas pada para pengurus; Materi INR berbasis kitab kuning diawali dengan meteri bersifat teoritis seperti aqidah islam; kaidah hukum fiqih ibadah-mu'amalah; dan wawasan keislaman. Adapun materi praktek keislaman berupa pelaksanaan sholat berjama'ah; penyembelihan hewan kurban; infak, shodaqah, zakat, dan wakaf; berumrah dan berhaji; dan pelaksanaan kegiatan ramadhan.

\section{DAFTAR PUSTAKA}

Arikunto, S. 2006. Prosedur Penelitian Suatu Pendekatan Praktek. Jakarta: PT Rineka Cipta.

Badawi, Zaki. 1993. A Dictionary of The Social Sciences.Beirut: LibrairieDu Liban

Cohen L and Manion. 1994. Research Methods In Education. London: Routledge.

Mahsun. 2005. Metode Penelitian Bahasa: Tahapan strategi, metode, dan tekniknya. Jakarta: PT Raja Grafindo Persada.

Martin. 1986. "Intervening in the Process of Writing Development".

Nugraha.2011. Ekspresi Religiositas Urang Sunda Dalam Teks Islam Berbahasa Sunda.Dalam Proceedings International Seminar on Reformulating and Tranforming Sundanese Culture.Ministry of Tourism and culture.

Pusat Bahasa Depdiknas. 2005. Kamus Besar Bahasa Indonesia. Jakarta: Balai Pustaka.

Saragih, A.2012. Peran Bahasa dalam pembangunan Jati Diri dan karakter Bangsa. Dalam Indonesiaan Journal Of Systemic Functional Lingusitics. Vol.1,Number 1, Januari. Asosiasi SFL Indonesia.

Sugiyono. 2006. Metode Penelitian Kualitatif, Kuantitatif, and $R \& D$. Bandung: Alfabeta.

Tamsya, Budi. 2002. Kamus Lengkep: S-I, I-S, S-S. Bandung: Pustaka Setia.

Hayati. 2011. Papagon Hirup Masyarakat Sunda Kampung Naga. masyarakat Sunda Kampung Naga memiliki budaya papagon hirup Hayati (2011) Hayati (2011) http://penelitian.lppm.upi. edu/detil/1441/model-penanaman-nilai-nilaikearifan-lokal-(local-genius)-pada-masyarakatsunda, diakses tanggal 15 Februari 2015. 